\section{Australian Journal of \\ Crop Science}

\title{
Root system development and proline accumulation in sugarcane leaves under aluminum $\left(\mathrm{Al}^{3+}\right)$ stress
}

\author{
Luana Jandhy Mantovanini ${ }^{1}$, Renan Gonçalves da Silva ${ }^{1}$, Jóice de Oliveira Leite Silva ${ }^{2}$, Thiago Mateus Rosa \\ dos Santos ${ }^{1}$, Durvalina Maria Mathias dos Santos ${ }^{1}$, Sonia Marli Zingaretti ${ }^{2}$
}

\author{
'São Paulo State University (UNESP, School of Agriculture and Veterinarian Sciences Jaboticabal), 14884900, São \\ Paulo, Brazil \\ ${ }^{2}$ Biotechnology Unit, University of Ribeirão Preto, 14096380, São Paulo, Brazil
}

Corresponding author: szingaretti@unaerp.br

\begin{abstract}
The potential of sugarcane as a food and bioenergy crop is currently driving the expansion of sugarcane production areas throughout the world. This crop may be constantly subjected to unusual environments such as acid soils with aluminum in toxic form $\left(\mathrm{Al}^{3+}\right)$, leading to problems in cultivation when the soil is not properly prepared. The aim of this research was to select most tolerant sugarcane genotypes to aluminum toxicity by determining root growth and proline content in the leaves. The experiment employed a factorial that was entirely randomized, with four sugarcane genotypes (CTC-2, CTC-14, RB855453, and RB966928) combined with aluminum concentrations $\left(45,88,221,444,600,897,1000 \mu \mathrm{mol} \mathrm{L}^{-1}\right)$, with three replications. Our results suggest that CTC-2 showed higher tolerance to aluminum, with more biomass accumulation in roots when compared to the other genotypes (descending order of tolerance: CTC-2 > CTC-14 > RB855453 > RB966928). Proline level was clearly different for tested genotypes. CTC- 2 showed an increase of $58 \%$ in the proline level, while genotype RB 855453 showed a $24 \%$ increase, but only when the aluminum concentration was $897 \mu \mathrm{molL}^{-1}$.
\end{abstract}

Keywords: Abiotic stress; Osmoprotector; Roots; Saccharum spp.; Toxicity.

\section{Introduction}

Sugarcane is considered one of the main crops of the world's agro-industry and, in this scenario, Brazil figures as the leading producer with the highest export rates (UNICA, 2017). The increase in sugarcane production in the last decades has led to the expansion of the cultivated areas and, nowadays, covers a large part of the Brazilian territory, including areas with aluminum (Al) toxicity, a common problem of acidic soils $(\mathrm{pH}<5.5)$. In general, it is known that abiotic factors such as high temperature, water availability and soil $\mathrm{pH}$ affect agricultural productivity (Singh et al., 2017). About 30 to $40 \%$ of the world's arable soils are affected by $\mathrm{Al}$ toxicity. In acid soils, aluminum turns into its toxic form $\left[\mathrm{Al}\left(\mathrm{H}_{2} \mathrm{O}\right)_{6}\right]^{3+}$, which has been associated with severe changes in the root system (Horst et al., 2010; Rao et al., 2016). Those changes include inhibition of the root elongation zone, alteration in ethylene and auxin biosynthesis and distribution, interference in cell division in root tips and lateral roots.

Aluminum toxicity is also associated with increases in cell wall rigidity by cross-linking pectin; decreases in root respiration, decreases in cell-wall polysaccharides deposition, and modification of plasma membrane structure and function (Kopittke et al., 2015; Sade et al., 2016).
This growing scenario promotes the constant search for genotypes that are productive and adapted to the most different environmental conditions. The selection of genotypes based on morphological, physiological and biochemical parameters has been shown to be effective (Ahamad, et al., 2015). In addition to root elongation, the increases in biomass and organic solutes, such as the level of proline under the effect of aluminum stress have also been considered (Giannakoula et al., 2008; Carlin and Santos, 2009; Khan et al., 2000). Proline is an amino acid that plays an important role in plants. It protects from several stresses and helps plants to recover more quickly (Hayat et al., 2012). Apart from acting as an osmolyte for osmotic adjustment, proline also contributes to stabilizing sub-cellular structures (Ashraf and Foolad, 2007). Several authors have verified proline accumulation in plants under toxic aluminum conditions (Ali et al., 2008; Nahar, et al., 2017). An increase in proline content induced by aluminum toxicity has also been reported in corn (Khan et al., 2000) sorghum (Zaifnejad et al., 1997) and mung bean (Nahar, et al., 2017).

In order to select genotypes that are more resistant to aluminum stress, the aim of the present study was to evaluate four sugarcane genotypes in early vegetative stage for the morphological alterations in roots and the proline content in leaves under increased Al concentration. The 
response of sugarcane genotypes to the presence of toxic aluminum form in the soil is an important issue for the establishment of the crop and its genetic improvement.

\section{Results and Discussion}

\section{Roots biometric data}

Analyzing the effect of the different concentrations of $\mathrm{Al}^{3+}$ on the root area, the difference between the genotypes became evident. Although the presence of aluminum significantly reduced the CTC-2 genotype root area (50\%) even under the lower Al concentration $\left(45 \mu \mathrm{mol} \mathrm{L}^{-1}\right)$, CTC-2 was significantly superior to the genotypes that remained unchanged. The other genotypes, CTC-14, RB966928 and RB855453, showed no accentuated reduction of the root area. At $1000 \mu \mathrm{mol} \mathrm{L}^{-1}$, the CTC-2 genotype showed an area over $2,500 \mathrm{dm}^{2}$, statistically superior to the other genotypes (approximately 2,000 $\mathrm{dm}^{2}$ for genotypes RB966928 and CTC14 , and $1,500 \mathrm{dm}^{2}$ for genotype RB855453). Genotype RB966928 remained practically constant regardless of increased aluminum concentrations in the solution (Fig. 1). Similar results were found by Marin and Santos (2008), who reported a significant reduction of root density at minimum values of $\mathrm{Al}^{3+}\left(0.71 \mathrm{mmol} \mathrm{dm}{ }^{3}\right)$. One of the first effects of aluminum toxicity is the inhibition of root elongation; the ionic forms of aluminum act by destroying the cell structure of the root apex, thus affecting water and nutrient uptake by the roots affecting plant development (Zheng, 2010).

The root length density (RLD) of the CTC-2 genotype showed higher indices in the different concentrations than the other genotypes. Genotype RB855453 maintained the same response at the different concentrations, but when compared to genotype CTC-2, it showed a significant reduction in root density at almost all concentrations, differing only in concentrations of $88 \mu \mathrm{mol} \mathrm{L}^{-1}$ and $600 \mu \mathrm{mol}$ $\mathrm{L}^{-1}$. The CTC-14 and RB966928 genotypes showed similar response at moderate concentrations, $221 \mu \mathrm{mol} \mathrm{L}^{-1}$ (Fig.2). RLD has been used as a good descriptor of resource use efficiency and may indicate the potential of water and nutrient uptake of a vegetation holder (Soethe et al. 2006). The rate of root length density was the morphological parameter that most contributed to the evaluation of the tolerance of the varieties to $\mathrm{Al}$, and depends on the interaction between genotypes and the concentration of Al. Although the CTC genotype had shown a reduction in dry mass production under aluminum stress, when compared to the others, its production remains higher even at high concentrations (above $444 \mu \mathrm{mol} \mathrm{L}^{-1}$ ) (Fig. 3).

With the addition of aluminum to the nutrient solution, genotypes CTC-14 and RB855453, in $1000 \mu \mathrm{mol} \mathrm{L} \mathrm{L}^{-1}$, presented lower dry weight, 0.052 and $0.048 \mathrm{~g}$ respectively. In addition, there was a $28 \%$ reduction in dry mass for genotype CTC-14, which decreased from $0.059 \mathrm{~g}$ under the control condition to $0.043 \mathrm{~g}$ when the aluminum dose was $88 \mu \mathrm{mol} \mathrm{L} \mathrm{L}^{-1}$. Therefore, it behaved more consistently to stress reducing the dry mass as the aluminum concentration increased. Among the evaluated genotypes, RB855453 obtained a lower amount of dry mass when subjected to the dosages of 221 and $1000 \mathrm{mmol} \mathrm{L}^{-1}$ (intermediate and maximum aluminum dosage levels) (Fig. 3). As a result, plants exposed to aluminum toxicity present root growth and transport reduction, reduced use of nutrients and less biomass production (Tabaldi et al., 2007). The reduction of dry mass was also observed by Custódio et al. (2002), and Crestani et al. (2009), who evaluated the stress by aluminum in monocotyledons under hydroponic conditions.

\section{Proline content}

Proline level was not similar for the different genotypes. CTC -2 was the first to show an increase of $58 \%$ in the proline level at $45 \mu \mathrm{mol} \mathrm{L}^{-1}$ and a further increase $(72,4 \%)$ at 444 $\mu \mathrm{mol} \mathrm{L}^{-1}$ aluminum concentration. Genotype RB966928 had a lower proline level, maintaining similar values to the control condition. At $1000 \mu \mathrm{mol} \mathrm{L}^{-1}$, the RB855453 and CTC-14 genotypes proline levels were also similar to the control condition; CTC-14 showed an increase at $444 \mu \mathrm{mol} \mathrm{L}^{-1}$, and RB855453 only at $1000 \mu \mathrm{mol} \mathrm{L}^{-1}$. The increase on proline content associated to stress has been reported for different crops: sorghum (Zaifnejad et al., 1997); corn (Khan et al., 2000), and mung bean (Nahar, et al., 2017). In sugarcane specifically, Carlin and Santos (2009), evaluated the interaction of Al stress and water deficit in the sugarcane genotype IAC91-5155. The results indicated an increase of $19 \%$ of proline content associated with increased aluminum levels and moderate water deficit.

It is well known that aluminum toxicity in plants is associated to the inhibition of root density and growth, cellular damages, reduction of photosynthetic pigments, electron transport, and photosynthesis, compromising plant development (Mossor-Pietraszewska, 2001). The amino acid proline is considered the key metabolite for the osmotic adjustment of plants under water stress and aluminum toxicity by accumulating in the cells with osmoprotective function, reducing toxic ions, and increasing water content (Cayley et al., 1992; Giannakoula et al., 2008).

Proline is also involved in ROS scavenging (Ahmad et al. 2015), protecting cell membranes from deleterious effects caused by reactive oxygen species (ROS), preventing protein denaturation, preserving the structure of enzymes, and acting as a buffer to regulate cellular redox potential (Sharma and Dubey, 2005; Ashraf and Foolad, 2007).

On CTC-2, root growth was not inhibited by increased amounts of aluminum, as it was for others genotypes (Fig.2). This genotype also has the highest detected proline level, where increased amounts were determined at 45, 444 and $600 \mu \mathrm{mol} \mathrm{L}^{-1}$ (Fig.4). As proline has the ability to act as an osmoprotector and keep the water content associated to its ability of recovering photosynthetic pigments, this may cause the increase of photosynthesis and prevent root inhibition.

\section{Materials and Methods}

\section{Plant materials}

Sugarcane genotypes CTC-2, CTC-14, RB855453 and RB966928 were selected from the most commonly planted genotypes in the large sugarcane growth areas in Brazil (Marin, 2008). Mini-tots provided by São Martinho Sugar and Ethanol factory (São Paulo, Brazil), were pre-germinated in $700 \mathrm{ml}$ plastic containers containing plant soil for 20 days. 


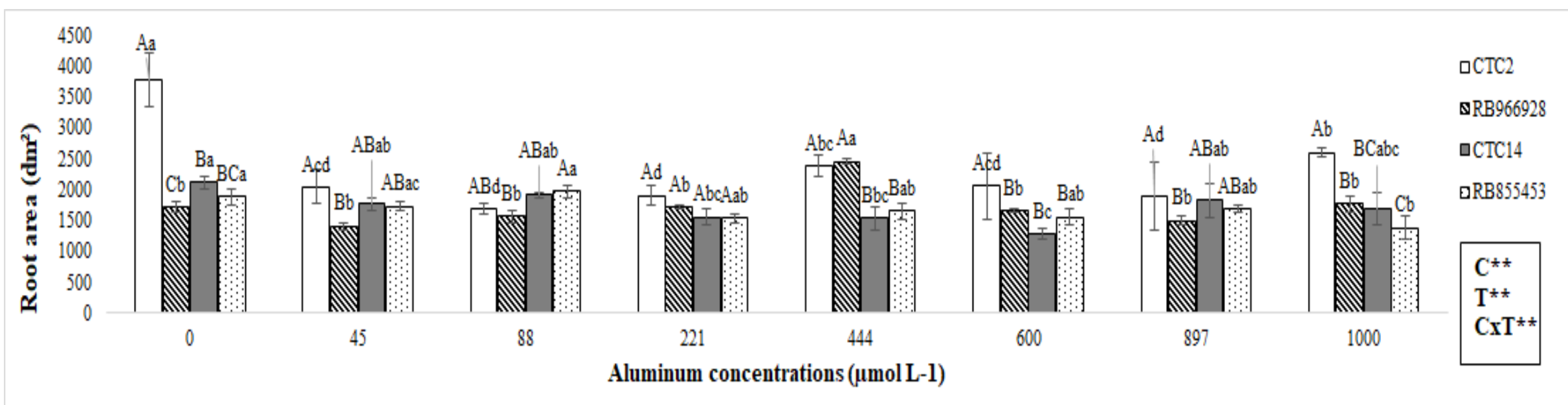

Fig 1. Roots area (RA) in young sugarcane plants under $\mathrm{Al}^{3}$ concentrations. Non-significant $\mathrm{F}^{\text {ns }}$ test, $* \mathrm{p}<0.05, * * \mathrm{p}<0.01$. Equivalent capital letters (at each concentration of Al) and lower case letters (between Al concentrations) did not differ statistically from each other by Tukey's test $(p<0.05)$. The bars indicate the standard deviation of the average of three replicates.

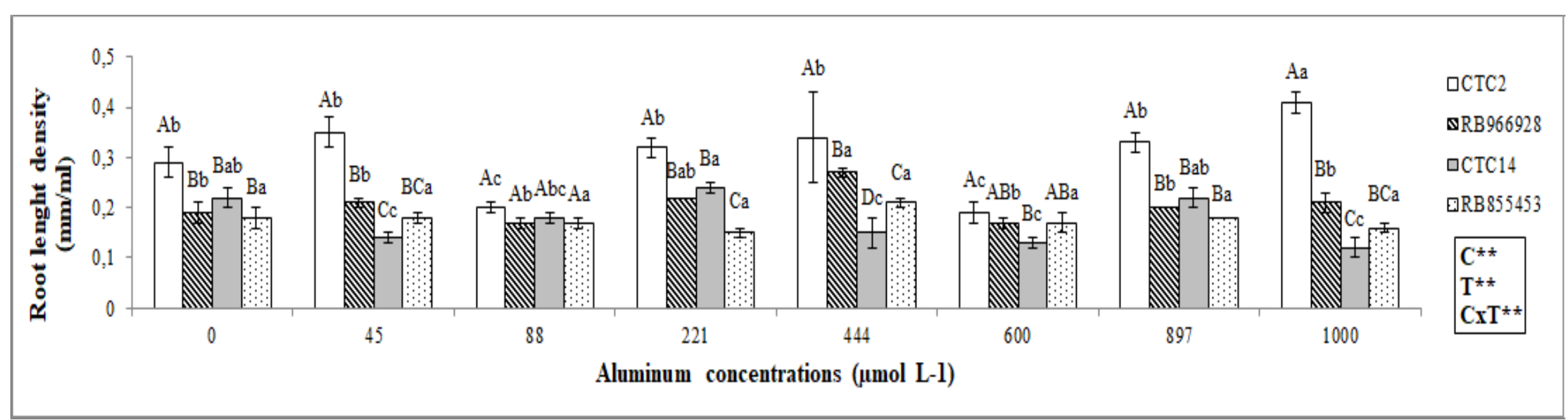

Fig 2. Root length density (RLD) in young sugarcane plants under $\mathrm{Al}^{3}$ concentrations. Non-significant $\mathrm{F}^{\mathrm{ns}}$ test, ${ }^{*} \mathrm{p}<0.05 ;{ }^{* *} \mathrm{p}<0.01$. Equivalent capital letters (at each concentration of $\mathrm{Al}$ ) and lower case letters (between Al concentrations) did not differ statistically from each other by Tukey's test $(p<0.05)$. The bars indicate the standard deviation of the average of three replicates. 


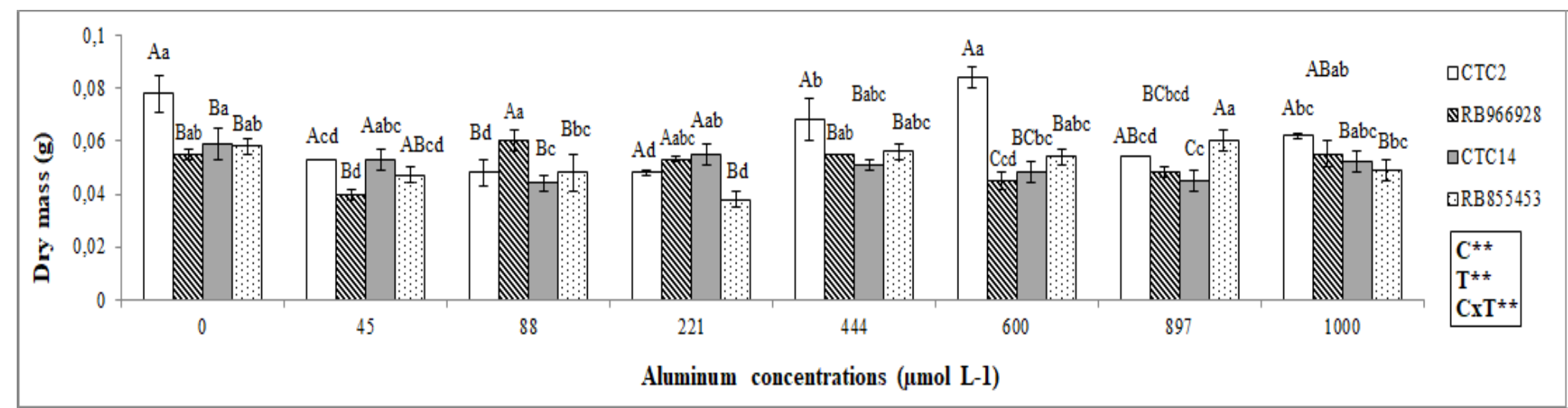

Fig 3. Dry mass of roots (DM) in young sugarcane plants under $\mathrm{Al}^{3}$ concentrations. Non-significant $\mathrm{F}^{\text {ns }}$ test, ${ }^{*} \mathrm{p}<0.05, * * \mathrm{p}<0.01$. Equivalent capital letters (at each concentration of Al) and lower case letters (between Al concentrations) did not differ statistically from each other by Tukey's test $(p<0.05)$. The bars indicate the standard deviation of the average of three replicates.

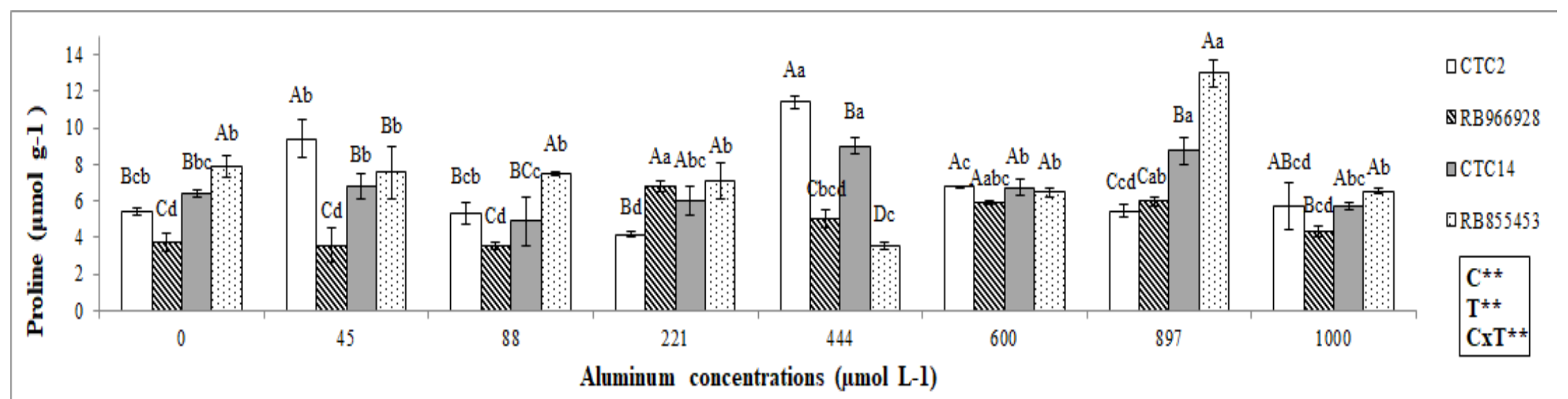

Fig 4. Proline accumulation in leaves (PRO) in young sugarcane plants under $\mathrm{Al}^{3}$ concentrations. Non-significant $\mathrm{F}^{\text {ns }}$ test, ${ }^{*} \mathrm{p}<0.05, * * \mathrm{p}<0.01$. Equivalent capital letters (at each concentrat|on of Al) and lower case letters (between Al concentrations) did not differ statistically from each other by Tukey's test $(p<0.05)$. The bars indicate the standard deviation of the average of three replicates. 


\section{Conduction of the experiment}

Plants with similar stem and root length were selected and transferred to a hydroponic system in $16 \mathrm{~L}$ of nutrient solution (Hoagland and Arnon, 1950), where they remained in acclimation for seven days. After this period, aluminum chloride hexahydrate $\left(\mathrm{AlCl}_{3}{ }_{6} \mathrm{H}_{2} \mathrm{O}\right)$ in the concentrations of 0 $\mu \mathrm{mol} \mathrm{L}^{-1}$ (control) and $45 ; 88 ; 221 ; 444 ; 600 ; 897$, and 1,000 $\mu \mathrm{mol} \mathrm{L}{ }^{-1}$ was added to the nutrient solution. The experiment was conducted in a greenhouse at a temperature of $25.8 \pm$ $2{ }^{\circ} \mathrm{C}$ and $75 \pm 10 \%$ relative humidity in the Biotechnology Unit of University of Ribeirão Preto (UNAERP), São Paulo. The $\mathrm{pH}$ of the nutrient solution was maintained at 4.5 by the addition of $\mathrm{HCl}$ when necessary, maintaining the aluminum molecule in its toxic form $\left(\mathrm{Al}^{3+}\right)$. After seven days, to ensure the early development stage, roots and leaves were collected for physiological analysis.

\section{Measured traits}

The genotypes were evaluated according to the biometric parameters: root length density (RLD), area (A) and dry mass (DM)). For area $\left(\mathrm{dm}^{2}\right)$ and density $\left(\mathrm{mm} \mathrm{cm}^{-3}\right)$ determination, total roots of each plant were stained with methylene blue (10 $\mathrm{mg} / \mathrm{ml}$ ) for approximately two minutes following the previously described procedure (Bouma et al., 2000) after being rinsed; root image was taken by a Hewlett Packard Model 5C scanner and analyzed by Delta-T Scan Root Analysis System software. To determine the dry mass, roots were dried in a forced air circulation oven at $80{ }^{\circ} \mathrm{C}$ to constant mass and measured using the Denver Instrument Company AA-200 analytical scale.

Proline content quantification of fresh leaves was performed using $1 \%$ ninhydrin solution (Sigma, USA) prepared in glacial acetic acid:water $(60: 40, v / v)$. An aliquot of $0.5 \mathrm{~mL}$ of the sample was added to a test tube with $2 \mathrm{~mL}$ of the ninhydrin solution (Bates et al. 1973).

The absorbance was measured at $520 \mathrm{~nm}$ on a Beckman DU 640 spectrophotometer. The determination of the content was calculated based on the dry mass according to the formula:

$\mu \mathrm{mol} \mathrm{g}{ }^{-1}$ of dry mass $=\frac{\left[\frac{\left(\frac{\mathrm{\mu g} \text { proline }}{\mathrm{ml}} \times \mathrm{ml} \text { toluene }\right)}{(115.5 \mu \mathrm{g} / \mathrm{\mu mole})}\right]}{\left(\frac{\mathrm{g} \text { sample }}{5}\right)}$

\section{Experimental design and statistical analysis}

Four genotypes were evaluated in a randomized $4 \times 8$ factorial scheme with three replications. The resulting data were submitted to AgroEstat - System for Statistical Analysis of Agronomic Tests, version 1.1.0 (Barbosa and Maldonado, 2014). The averages were compared by the Tukey test at $5 \%$ probability.

\section{Conclusion}

The presence of aluminum significantly reduced the biometric parameters in roots among the genotypes. CTC-2 showed the highest values for RA, RLD, DM, and proline content when compared to the other genotypes, proving to be the most tolerant genotype even at high concentrations of aluminum.

\section{Acknowledgments}

This research was supported by the Research Grand No 14/19667-8 from FAPESP - Brazil.

\section{References}

Ahmad P, Sarwat M, Bhat NA, Wani MR, Kazi AG, Tran LS (2015) Alleviation of cadmium toxicity in Brassica juncea L. (Czern. \& Coss.) by calcium application involves various physiological and biochemical strategies. PLoS One. 28:10(1).e0114571.

Ali, B, Hasan, SA, Hayat, S,Hayat, Q, Yadav, S, Fariduddin, Q, Ahmad, A (2008) A role for brassinosteroids in the amelioration of aluminium stress through antioxidant system in mung bean (Vigna radiata L. Wilczek). Environ Exp Bot. 62(2):153-159.

Ashraf M, Foolad MR (2007) Roles of glycine betaine and proline in improving plant abiotic stress resistance.Environ Exp Bot. 59:206-216.

Bambolin A, Caione G, Souza NF, Seben-Junior GF, Ferbonink GF (2015) Calcário líquido e calcário convencional na correção da acidez do solo. Rev Agric Neotrop. 2:34-38.

Barbosa JC, Maldonado-Junior W (2014) Agroestat: sistema para análises estatísticas de ensaios agronômicos. Jaboticabal: FCAV, Version 1.1.0.712.

Bates LS, Waldren RP, Teare ID (1973) Rapid determination of free proline for water-stress studies. Plant Soil. 39:205207.

Bouma TJ, Nielsen KL, Koutstaal BAS (2000) Sample preparation and scanning protocol for computerized analysis of root length and diameter. Plant soil.218:185196.

Carlin SM, Santos DMM (2009) Indicadores fisiológicos da interação entre déficit hídrico e acidez do solo em canade-açúcar. Pesq Agropec Bras.44:1106-1113.

Cayley, S, Lewis, BA, Record, JMT (1992) Origins of the osmoprotective properties of betaine and proline in Escherichia coli K-12. J Bacteriol. 174:1586-1595.

Crestani M, Carvalho FIF, Oliveira AC, Silva JAG, Souza VQ, Parachu EAM, Silveira G, Ribeiro G, Luche HS (2009) Estresse por alumínio em genótipos de aveia preta em condição hidropônica. Bragantia. 68(3):639-649.

Custódio CC, Bomfim DC, Saturnino, SM, Machado Neto NB (2002) Estresse por alumínio e por acidez em cultivares de soja. Sci Agric. 59(1):145-153.

Giannakoula A, Moustakas M, Mylona P, Papadakis I, Yupsanis $T$ (2008) Aluminum tolerance in maize is correlated with increased levels of mineral nutrients, carbohydrates and proline, and decreased levels of lipid peroxidation and Al accumulation. J Plant Physiol. 165:385396.

Hayat S, Hayat Q, Alyemeni MN, Wani A, Pichtel J, Ahmad A (2012) Role of proline under changing environments. Plant Signal Behav. 7(11):1456-1466.

Hoagland DR, Arnon DI (1950) The water-culture method for growing plants without soil. Circ - Calif Agric Exp Stn. 347:1-32. 
Horst WJ, Wang Y, Eticha D (2010) The role of the root apoplast in aluminium-induced inhibition of root elongation and in aluminium resistance of plants: a review. Ann Bot. 106(1):185-197.

Khan AA, Mcneilly T, Collins C (2000) Accumulation of amino acids, proline, and carbohydrates in response to aluminum and manganese stress in maize. J Plant Nutr. 23(9):13031314.

Kopittke PM, Moore KL, Lombi E, Gianoncelli A, Ferguson BJ, Blamey FPC, Menzies NW, Nicholson TM, McKenna BA, Wang P, Gresshoff PM, Kourousias G, Webb RI, Green K, Tollenaere A (2015) Identification of the primary lesion of toxic aluminum in plant roots. Plant Physiol. 167:14021411.

Marin A, Santos DMM (2008) Interação da deficiência hídrica e da toxicidade do alumínio em guandu cultivado em hidroponia. Pesq Agropec Bras. 43(10):1267-1275.

Marin FR (2008) Árvore do conhecimento cana-de-açúcar, variedades. Ageitec - Embrapa. Available in: <http://www.agencia.cnptia.embrapa.br/gestor/cana-deacucar/arvore/CONTAG01_42_1110200717570.html>, accessed in 2018 February.

Mossor-Pietraszewska, T (2001) Effect of aluminium on plant growth and metabolism. Acta Biochim Pol. 48(3):673-686.

Nahar K, Hasanuzzaman M, Suzuki T, Fugita M (2017) Polyamines-induced aluminum tolerance in mung bean: $\mathrm{A}$ study on antioxidant defense and methylglyoxal detoxification systems. Ecotoxicology. 26: 58-73.

Rao IM, Miles JW, Beebe SE, Horst WJ (2016) Root adaptations to soils with low fertility and aluminium toxicity. Ann Bot. 118(4):593-605.
Sade H, Meriga B, Surapu V, Gadi J, Sunita MS, Suravajhala P, Kavi Kishor PB (2016) Toxicity and tolerance of aluminum in plants: tailoring plants to suit to acid soils. Biometals. 29(2):187-210.

Sharma P, Dubey RS (2005) Modulation of nitrate reductase activity in rice seedlings under aluminium toxicity and water stress: role of osmolytes as enzyme protectant. J Plant Physiol. 162:854-864.

Singh S, Tripathi DK, Singh S, Sharma S, Dubey NK, Chauhan DK, Vaculík M (2017) Toxicity of aluminium on various levels of plant cells and organism: a review. Environ Exp Bot. 137:177-193.

Soethe N, Lehmann J, Engels C (2006) The vertical pattern of rooting and nutrient uptake at different altitudes of a south Ecuadorian montane forest. Plant Soil. 286:287-299.

Tabaldi LA, Nicoloso FT, Castro GY, Cargnelutti D, Gonçalves JF, Rauber R, Skrebsky EC, Schetinger MRC, Morsch VM, Bisognin DA (2007) Physiological and oxidative stress responses of four potato clones to aluminum in nutrient solution. Braz J Plant Physiol. 19(3):211-222.

União da Indústria de Cana de Açúcar -UNICA (2017) Histórico de exportação mensal de etanol pelo Brasil, por região. Available in: <http://www.unicadata.com.br/listagem.php?idMn=65>, accessed in 2017 August.

Zaifnejad, M, Clark, RB, Sullivan, CY (1997) Aluminum and water stress effects on growth and proline of sorghum. J Plant Physiol, 150(3):338-344.

Zheng SJ (2010) Crop production on acidic soils: overcoming aluminium toxicity and phosphorus deficiency. Ann Bot. 106(1):183-184. 